\title{
Review Article: URIC ACID HOMEOSTASIS AND DISTURBANCES
}

\author{
Ferry Fredy Karwur ${ }^{1,2}$, Dwi Rahayu Pujiastuti ${ }^{1}$ \\ ${ }^{1}$ Master Program of Biology, ${ }^{2}$ Faculty of Medicine and Health Sciences, Satya Wacana Christian University
}

\begin{abstract}
ABSTRAK
Review ini mengkaji mengenai homeostasis asam urat di dalam tubuh manusia dan menganalisis studi terbaru mengenai variabelvariabel utama yang memengaruhinya. Konsentrasi asam urat subjek normal pria adalah 3,5-7,2 mg/dL dan wanita adalah 2,6-6 $\mathrm{mg} / \mathrm{dL}$. Turnover harian asam urat tubuh normal berkisar 498-1392 mg/hari, miscible pool 767-1650 mg, reabsorbsi $8064 \mathrm{mg} / \mathrm{hari}$, ekskresi melalui ginjal 262-620 mg/hari dan usus 186-313 mg/hari. Dinamika asam urat dipengaruhi oleh faktor makanan, minuman, usia, riwayat penyakit, dan genetik. Konsumsi makanan purin tinggi meningkatkan asam urat darah sebesar 1-2 mg/dL, minuman berfruktosa 213-290 g/hari meningkatkan 0.52-1.7 mg/dL, sukrosa $1.5 \mathrm{~g} / \mathrm{kgBB}$ meningkatkan 0.61 mg/dL, dan bir 10-20 $\mathrm{ml} / \mathrm{kgBB}$ meningkatkan 0.50-0.92 mg/dL. Gen ABCG2 berperan untuk membawa asam urat keluar dari tubuh sebesar 114.31$162.73 \mathrm{mg} / \mathrm{dL}$, SLC2A9 sebesar 5.43-20.17 mg/dL, dan SLC22A12 sebesar 5.77-6.71 mg/dL. Data tersebut menggambarkan homeostasis asam urat tubuh dan besarnya dampak faktor lingkungan (konsumsi makanan, minuman, dan lifestyle) maupun genetik. Pemahaman homeostasis asam urat dan gangguannya penting dalam pengelolaan penyakit, apakah itu hiperurisemia ataupun sebaliknya hipourisemia. (FMI 2017;53:292-298)
\end{abstract}

Kata kunci: Homeostasis; asam urat; gangguan

\begin{abstract}
This review examined the homeostasis of uric acid in human body and analyzed recent studies of the affecting major variables. Normal uric acid concentration in male is $3.5-7.2 \mathrm{mg} / \mathrm{dL}$ and in female is 2.6-6 $\mathrm{mg} / \mathrm{dL}$. Daily turnover of normal uric acid ranges from 498-1392 mg/day, miscible pool is $767-1650 \mathrm{mg}$, reabsorption is $8064 \mathrm{mg} /$ day, renal excretion is 262-620 mg/day and intestine 186-313 mg/day. The dynamics of uric acid is influenced by factors of food, drink, age, history of disease, and genetic. High purine dietary consumption increases blood uric acid by $1-2 \mathrm{mg} / \mathrm{dL}, 213-290 \mathrm{~g} /$ day fructose drinks increases $0.52-1.7 \mathrm{mg} / \mathrm{dL}, 1.5 \mathrm{~g} / \mathrm{kgBW}$ sucrose increases $0.61 \mathrm{mg} / \mathrm{dL}$, and $10-20 \mathrm{ml} / \mathrm{kgBW}$ beer increases $0.50-0.92 \mathrm{mg} / \mathrm{dL}$. The ABCG2 gene plays a role in bringing uric acid out of the body by 114.31-162.73 mg/dL, SLC2A9 of 5.43-20.17 mg/dL, and SLC22A12 of 5.77-6.71 mg/dL. The data described the homeostasis of uric acid and the magnitude of the impact of environmental (consumption of food, beverages, and lifestyle) and genetic factors. Understanding uric acid homeostasis and its disturbances is important in managing diseases as a consequence of hyperuricemia and hypouryscemia (FMI 2017;53:292-298)
\end{abstract}

Keywords: Homeostasis; uric acid; disturbances

Correspondence: Ferry Fredy Karwur, Master Program of Biology, Satya Wacana Christian University, Jalan Diponegoro No. 52-60 Sidorejo, Salatiga, Jawa Tengah. Email: ferry.karwur@staff.uksw.edu

\section{INTRODUCTION}

Uric acid (C5H4N4O3) (IUPAC: 7,9-dihydro-3H-purine-2,6,8-trione) is a heterocyclic compound found in many organisms. In birds, reptiles, and insects, uric acid is almost insoluble and is a nitrogenous waste product. In certain mammals, uric acid is found in blood and urine, and is the final form of purine metabolism. In primates, uric acid is the result of the catabolism of nucleic acids and proteins, then is discarded with urine. Plants also produce uric acid. Hauck et al (2014) found that uric acid accumulates throughout the Arabidopsis tissues when urate oxidase (UOX) genes mutate. Algae in symbiosis with marine anemones were initially suspected to accumulate a lot of potassium oxalate, but after being identified, it turned out to be uric acid (Clo- de et al 2009). In addition, microorga-nisms such as fungi and some bacteria (Enterobacteria and Bacillus spp.) produce uric acid as an intermediate, then it is converted into ammonia as the final product for excretion (Vogels \& van der drift 1976, Lee et al 2013).

In humans, uric acid is maintained at homeostasis condition to be beneficial to the body. However, uric acid homeostasis can exceed their minimum and maximum limits which is largely influenced by a number of factors, including exogenous factors, processes in the body, and uric acid excretion. Exogenous factors can be foods and beve-rages that contribute to increased production of uric acid in addition to cellular catabolism in the body. The ex-cretion of uric acid becomes the key factor to maintaining balance. Important questions arise. 
What is the basal concentration of uric acid in the body? And what is the contribution of uric acid removal to homeostasis, and what is involved in the regulation? A study is needed to explain quantitatively the homeostasis and dynamics of uric acid, and this review examined the homeostasis of uric acid in human body and analyzed recent studies of the affecting major variables.

\section{LITERATURE REVIEW}

\section{Uric acid homeostasis}

In this section, the reversion of uric acid to the blood and its excretion from the body will be assessed quantitatively to form a model of uric acid homeostasis.

\section{Exogenous and endogenous factors}

Several studies have shown that exogenous and endogenous factors affect the amount of soluble acid (miscible pool) and the rate of urinary turnover in both normal and gout subjects (Table 1), as proven by some experiments using isotope uric acid. Studies using diet with low protein or purine content showed basal miscible pool of 767-1650 mg and turnover rate of 498-1392 $\mathrm{mg} /$ day in normal subjects, and very high miscible pool in gout patients.

\section{Sexual identity and uric acid}

Men and women have different ranges of concentrations of uric acid in the blood. The difference is due to physiological factors that affect uric acid metabolism in the body. The average level of uric acid in the blood of normal men ranges from $3.74-6.2 \mathrm{mg} / \mathrm{dL}$, while that in women ranges from $4-5.3 \mathrm{mg} / \mathrm{dL}$ (Table 2).

\section{Reabsorption and uric acid extraction}

Two-third of the uric acid is excreted through the kidney and the rest is through the intestine. Several studies have shown quantitative data on uric acid excretion. Data in Table 3 show that uric acid excretion in urine in normal subjects ranges from 262-620 $\mathrm{mg} /$ day. Whereas, in the intestine, uric acid excretion in urine in normal subjects ranges from $186-313 \mathrm{mg} / \mathrm{day}$.

Table 1. Summary of miscible pool and uric acid turnover rate observation

\begin{tabular}{|c|c|c|c|c|c|}
\hline \multirow{2}{*}{ Diet } & \multicolumn{2}{|c|}{ Miscible pool (mg) } & \multicolumn{2}{|c|}{ Turnover rate (mg/day) } & \multirow{2}{*}{ References } \\
\hline & Normal & Gout & Normal & Gout & \\
\hline $\begin{array}{l}\text { Equivalent to } 2.4-3.1 \\
\mathrm{mg} / \text { day } \mathrm{AU} \text { in urine }\end{array}$ & $1100-1300$ & $4742-18450$ & $690-870$ & $2485-8530$ & $\begin{array}{l}\text { Benedict et al } \\
\text { (1949) }\end{array}$ \\
\hline $\begin{array}{l}70 \mathrm{~g} \text { protein, } 350 \mathrm{~g} \\
\text { carbohydrate, } 100 \mathrm{~g} \text { fat }\end{array}$ & $946-1290$ & $1053-3078$ & $593-729$ & $535-1693$ & $\begin{array}{l}\text { Seegmiller et } \\
\text { al (1961) }\end{array}$ \\
\hline $\begin{array}{l}\text { Equivalent to } 200 \mathrm{mg} \\
\text { purin }\end{array}$ & $992-1650$ & $1248-3199$ & $602-838$ & $506-1542$ & $\begin{array}{l}\text { Scott et al } \\
(1969)\end{array}$ \\
\hline $\begin{array}{l}\text { (a) } 13 \mathrm{~g} \text { and (b) } 62 \mathrm{~g} \\
\text { protein }\end{array}$ & $\begin{array}{l}\text { (a) } 767-1485 \\
\text { (b) } 975-1469\end{array}$ & - & $\begin{array}{l}\text { (a) } 498-772 \\
\text { (b) } 1179-1392\end{array}$ & - & $\begin{array}{l}\text { Bowering et al } \\
\text { (1970) }\end{array}$ \\
\hline
\end{tabular}

Table 2. Mean concentrations of uric acid in the blood of men and women

\begin{tabular}{clccl}
\hline \multirow{2}{*}{ Sex } & \multicolumn{1}{c}{$\begin{array}{c}\text { Population } \\
\text { Origin }\end{array}$} & Mean Uric Acid $(\mathrm{mg} / \mathrm{dL})$ & $\begin{array}{c}\text { Range } \\
(\mathrm{mg} / \mathrm{dL})\end{array}$ & \multicolumn{1}{c}{ References } \\
\hline Male & - & $3.74-4.90$ & $2-7$ & Rehman \& Naqvi (1980) \\
& India & $5.8-6.2$ & $3.5-8.7$ & Das et al (2014) \\
& America & 6.07 & - & Choi \& Curhan (2007) \\
& Java, Indonesia & 6.2 & - & Darmawan (1988) \\
Female & - & $4-40$ & $2-6.4$ & Rehman \& Naqvi (1980) \\
& India & $4.3-5$ & $2.5-6.9$ & Das et al (2014) \\
& America & 4.65 & - & Choi \& Curhan (2007) \\
& Java, Indonesia & 5.3 & - & Darmawan (1988)
\end{tabular}


Table 3. Concentrations of uric acid released in urine and feces

\begin{tabular}{lcccl}
\hline \multicolumn{1}{c}{ Samples } & $\begin{array}{c}\text { Reabsorption } \\
(\mathrm{mg} / \text { day })\end{array}$ & $\begin{array}{c}\text { Urine } \\
(\mathrm{mg} / \text { day })\end{array}$ & $\begin{array}{c}\text { Feces } \\
(\mathrm{mg} / \text { day })\end{array}$ & \multicolumn{1}{c}{ References } \\
\hline Normal & - & $560-620$ & - & Benedict et al (1949) \\
Gout & - & $408-424$ & - & Nugent \& Tyler (1959) \\
Normal & 8064 & $436-618$ & - & Puig et al (2012) \\
Normal & - & $465-539$ & - & Sorensen (1962, 1965) \\
Normal & - & - & $186-200$ & Loffler et al (1981) \\
Normal & - & $262-321$ & $186-313$ & \\
Normal & - & $526-784$ & $478-631$ & \\
\hline Note: $(-)$ no data, $(*)$ normal subject given diet 4 g of RNA/day &
\end{tabular}

Table 4. Effect of foods on increased uric acid concentration

\begin{tabular}{lccl}
\hline \multicolumn{1}{c}{ Food Types } & $\begin{array}{c}\text { Amount of } \\
\text { Consumption }\end{array}$ & $\begin{array}{c}\text { Increase } \\
(\mathrm{mg} / \mathrm{dL})\end{array}$ & \multicolumn{1}{c}{ References } \\
\hline Meat, seafood, eggs, spinach & - & $1-2$ & Emmerson (1996), Fam (2002) \\
Meat & $>1.53$ times/day & 0.48 & Choi et al (2005) \\
Seafood & - & 0.16 & Choi et al (2005) \\
\hline
\end{tabular}

Table 5. Effects of alcohol, fructose and sucrose consumption on uric acid

\begin{tabular}{lccl}
\hline \multicolumn{1}{c}{ Beverage Types } & Total & Increase $(\mathrm{mg} / \mathrm{dL})$ & \multicolumn{1}{c}{ References } \\
\hline Beer & $10 \mathrm{ml} / \mathrm{kg} \mathrm{BW}$ & $0.50-0.59$ & Yamamoto et al (2004) \\
Beer $^{*}$ & $20 \mathrm{ml} / \mathrm{kg} \mathrm{BW}$ & $0.91-0.92$ & Moriwaki et al (2006) \\
Fructose & $213-219 \mathrm{~g} /$ day & 0.52 & Wang et al $(2012)$ \\
Fructose & $250-290 \mathrm{~g} /$ day & $1-1.7$ & Emmerson $(1974)$ \\
Sucrose & $1.5 \mathrm{~g} / \mathrm{kg} \mathrm{BW}$ & 0.61 & Kobayashi et al $(2007)$ \\
Other (green tea) & $1 \mathrm{cup} /$ day & 0.42 & Teng et al $(2013)$ \\
\hline Note: $(*)$ containing $5 \%$ ethanol and $56 \mathrm{mg} / \mathrm{L}$ purine & &
\end{tabular}

\section{Uric acid homeostasis and disturbances}

This section examines the effect of food and beverage consumption as well as the function of genetic component to uric acid homeostasis and its disturbances based on quantitative data.

\section{High purine-containing food}

It has long been established that consumption of high purine-containing food contributes to increased uric acid production (Emmerson 1974, Choi et al 2005). Types of food containing high purines such as meat, seafood, eggs, and spinach contribute to uric acid increase of about 1-2 mg/dL (Table 4) (Emmerson 1996, Fam 2002). However, the type, frequency, pattern, and amount of food consumed have major contribution to uric acid in the body.

\section{Effects of alcohol, fructose and sucrose}

Consuming alcohol, fructose and sucrose may increase the concentration of uric acid in the blood. Consuming beer as much as 10-20 ml/kgBW may increase uric acid as much as $0.50-0.92 \mathrm{mg} / \mathrm{dL}$. In contrast, alcoholic beverages, such as wine, are known not to contribute to increasing uric acid concentration in the body (Choi \& Curhan 2004). Consumption of fructose around 213-290 $\mathrm{g} /$ day may increase uric acid around 0.52-1.7 $\mathrm{mg} / \mathrm{dL}$. Whereas, consuming sucrose of $1.5 \mathrm{~g} / \mathrm{kgBW}$ may increase uric acid of $0.61 \mathrm{mg} / \mathrm{dL}$ (Table 5).

\section{Effects of food and beverage variation on uric acid}

Certain types of food and beverage consumption have no significant effect on the increase of uric acid concentration, and some even decrease. Epidemiological studies have shown that consumption of vegetables, milk, cheese, yogurt, black tea, coffee and vitamin supplements do not affect the increase of uric acid in blood (Choi et al 2005, Teng et al 2013, Ryu et al 2014). 
Table 6. Capacity of key genes in transporting uric acid in the kidneys

\begin{tabular}{lcl}
\hline \multicolumn{1}{c}{ Gen } & Capacity $(\mathrm{mg} / \mathrm{dL})$ & \multicolumn{1}{c}{ References } \\
\hline ABCG2 & $114.31-162.73$ & Nakayama et al (2011) \\
SLC2A9 & $5.43-20.17$ & $\begin{array}{l}\text { Caulfield et al (2008), Anzai et al (2008), Vitart et al } \\
\text { (2008), Bibert et al (2009), Witkowska et al (2012) }\end{array}$ \\
SLC22A12 & $5.77-6.71$ & Enomoto et al (2002) \\
\hline
\end{tabular}

\section{Influence of genetic background}

Recently, research on the human genome have grown rapidly. Genome-wide Association Studies (GWAS) has helped to analyze the genetic components associated with uric acid in population. The GWAS study has identified several gene loci associated with uric acid, including: ABCG2 (coded BCRP), SLC2A9 (GLUT9), SLC22A11 (OAT4), SLC22A12 (URAT1), SLC16A9, SLC17A1, LRCC16A, PDZK1, GCKR, MYL2-CUX2, and CNIH-2 (Kolz et al 2009, Reginato et al 2012, Yang et al 2014, Matsuo et al 2015).

Uric acid transporter genes were found to have pivotal roles in maintaining uric acid homeostasis and their polymorphisms imply disturbances leading to some serious diseases. Through functional studies using gene expression systems in model cells, several genes are known to have different capacity in trans-porting uric acid as indicated by Michaelis-Menten (Km) parameters (Table 6).

\section{DISCUSSION}

An interesting study from Gosling et al (2013) discussed the phenomenon of different uric acid levels in Pacific countries. Based on population studies, the data shown in most Pacific populations had a range of uric acid levels between $4-6 \mathrm{mg} / \mathrm{dL}$. If the normal range is 3-7 $\mathrm{mg} / \mathrm{dL}$, then the population in Pacific countries has a range of uric acid levels close to hyperuricemia. Possibly, some populations in the Pacific have shown different homeostatic changes as a result of adaptation to long term exposure to environment such as food or diseases. Unfortunately, these data were not supplemented by the development of uric acid over a period of time, making it difficult to answer whether at any given period the uric acid level is below the $4-6 \mathrm{mg} / \mathrm{dL}$ range. Then, what causes these levels to be close to hyperuricemia? Is it caused by environmental or genetic factors? Specifically in Indonesia, Gosling et al (2013) used population data in Java with a mean of $6.2 \pm 1.3 \mathrm{mg} / \mathrm{dL}$ of uric acid. The data were less represent-ative of the population in Indonesia due to different ethnic and geographical diversity (Karwur \& Triandhini 2016). It could be possible that the average uric acid in Indonesia is above or below the world population ave-rage. In essence, Gosling gave an idea that uric acid homeostasis in a population may change according to adaptation and tolerance of human survival.

According to some studies, certain food, such as red meat, seafood, and innards, contribute high uric acid in plasma. Not only foods, alcoholic and high fructosecontaining beverages that reflect a change in lifestyle also spur increased uric acid. However, studies of exogenous effects (food and beverages) still need to be studied in more detail to identify how much they increase uric acid in the body. Based on the cultural factors in the society, variations of food and beverages (including the number and frequency), and lifestyle vary in each country or region. For example, how much is the influence of alcoholic beverages of tuak, commonly consumed by some Indonesians, on the increase of uric acid in plasma? Can it be compared to wine or beer? Thus, the relationship between culture and local food types with increased uric acid should be studied in more detail.

Age, sex, history of disease and genetic factors are also known to affect the concentration of uric acid in plasma. Along with the increase of age, diet, lifestyle, and disease, uric acid can be potentially stable, decreased or increased. It should also be taken into consideration that ethnic factors influence tolerance to uric acid regulation. Based on sex, the factors of male and female are different because of physiological conditions of the body. Normal (healthy) premenopausal women have lower uric acid concentrations than men. It is predicted that the causes are estrogen and progesterone hormones which are diuretic or uricosuric. At postmenopause phase, the concentration will increase compared to that in premenopause phase (Rights \& Choi 2008). Disease factors also affect the concentration of uric acid. For example, disorders of the kidneys tend to affect increased uric acid in plasma.

Recent study has shown that genetic factors in the excretory system affects the homeostasis of uric acid in the body. The ABCG2 gene has the capacity to transport more than any other gene. This gene plays a major role in the excretion of uric acid to get out of the kidney and to remove it with urine. Furthermore, any interference or dysfunction may impact on the increase of uric acid in the plasma due to accumulation in the kidney. 
Another transporter gene is SLC2A9 (GLUT9) which acts as a uric acid reabsorption in the kidney. If the gene is impaired or dysfunctional (due to mutation), then there will potentially be hypouricemia or hyperuricemia. It has not been well known how SLC2A9 dysfunction mechanism can affect hypouricemia or hyperuricemia in the body. Transporter genes with dysfunction due to mutations are difficult to treat. If the gene function information can be utilized, then appropriate treatment settings and management of consumption and lifestyle will be better arranged.

The presence of uric acid in the blood can have implications for health and disease. Uric acid protects erythrocytes from lipid peroxides and lysis damage (Ames et al 1981). Other roles include protect-ing DNA damage from free radicals, activating the immune system by promoting T-cell directly, and maintaining blood pressure in salt-deprived environ-ment (Cohen et al 1984, Webb et al 2009).

\section{CONCLUSION}

Human body needs uric acid as it may have implications to health and disease. Basal normal uric acid homeostasis is as follows: turnover ranges from $498-1392 \mathrm{mg} /$ day, miscible pool is $767-1650 \mathrm{mg}$, reabsorption is 8064 $\mathrm{mg}$ /day, kidney excretion is $262-620 \mathrm{mg} /$ day and intestine is $186-313 \mathrm{mg} /$ day. The dynamics of uric acid is influenced by the factors of food, drink, age, history of disease, and genetic. The consumption of high purine foods increases uric acid of 1-2 mg/dL, 213-290 g/day fructose drinks increase $0.52-1.7 \mathrm{mg} / \mathrm{dL}, 1.5 \mathrm{~g} / \mathrm{kgBW}$ sucrose increases $0.61 \mathrm{mg} / \mathrm{dL}$, and $10-20 \mathrm{ml} / \mathrm{kgBW}$ beer increases $0.50-0.92 \mathrm{mg} / \mathrm{dL}$. Along with age, the accumulation of uric acid increases with decreasing organ function. ABCG2 gene expression plays a role in transporting uric acid out of the body of 114.31-162.73 $\mathrm{mg} / \mathrm{dL}, \mathrm{SLC} 2 \mathrm{~A} 9$ of $5.43-20.17 \mathrm{mg} / \mathrm{dL}$, and SLC22A12 of $5.77-6.71 \mathrm{mg} / \mathrm{dL}$. Less functional excretory system has a significant effect on uric acid accumulation in the body. In the management of hyperuricemic, hypouricemia and gout diseases, quantitative data play a significant role in determining the appropriate clinical treatment according to the physiological and genetic conditions of the patient.

\section{ACKNOWLEDGEMENT}

Dwi RP thanks to The Ministry of Education and Culture for the excellence scholarship to pursue Master Program in Biology at Satya Wacana Christian University, Salatiga.

\section{REFERENCES}

Ames BN, Cathcart R, Schwiers E, Hochstein P (1981). Uric acid provides an antioxidant defense in hu-mans against oxidant- and radical-caused aging and cancer: a hypothesis. Proc Natl Acad Sci USA 78, 6858-6862

Anzai N, Ichida K, Jutabha P, Kimura T, Babu E, Ji Jin C, Srivastava S, Kitamura K, Hisatome I, Endou H, Sakurai H (2008). Plasma urate level is directly regulated by a voltage-driven urate efflux transporter URATv1 (SLC2A9) in humans. The Journal of Biological Chemistry 283, 26834-26838

Benedict JD, Forsham PH, Stetten JrD (1949). The metabolism of uric acid in the normal and gouty human studied with the aid of isotopic uric acid. J Biol Chem 181, 183-193

Bibert S, Hess SK, Firsov D, Thorens B, Geering K, Horisberger J, Bonny O (2009). Mouse GLUT9: evidence for a urate uniporter. Am J Physiol Renal Physiol 297, 612-619

Bowering J, Calloway DH, Margen S, Kaufmann NA (1970). Dietary protein level and uric acid metabolism in normal man. J Nutrition 100, 249-261

Caulfield M, Munroe PB, O’Neill D, Witkowska K, Charchar FJ, et al (2008). SLC2A9 is a high-capacity urate transporter in humans. Plos Med 5, 1509-1523

Choi HK, Curhan G (2004). Beer, liquor, and wine consumption and serum uric acid level: the third national health and nutrition examination survey. Arthritis \& Rheumatism (Arthritis Care \& Research) 51, 1023-1029

Choi HK, Liu S, Curhan G (2005). Intake of purine-rich foods, protein, and dairy products and relation-ship to serum levels of uric acid: the third nation-al health and nutrition examinaton survey. Arthritis \& Rheumatism 52, 283-289

Choi HK, Curhan G (2007). Coffe, tea, and caffeine consumption and serum uric acid level: the third national health and nutrition examination survey. Arthritis \& Rheumatism (Arthritis Care \& Research) 57, 816-821

Clode PL, Sauders M, Maker G, Ludwig M, Atkins CA (2009). Uric acid deposits in symbiotic marine algae. Plant Cell and Environment 32, 170-17

Cohen AM, Aberdroth RE, Hochstein P (1984). Inhibition of free radical-induced DNA damage by uric acid. Febs Letters 174, 147-150

Culleton BF, Larson MG, Kannel WB, Levy D (1999). Serum uric acid and risk for cardiovascular disease and death: the Framinghan heart study. Ann Intern Med 131, 7-13

Darmawan J (1988). Rheumatic conditions in the northern part of Central Java an epidemiological survey. Thesis. Universiteit Rotterdam

Das M, Borah NC, Ghose M, Choudhury N (2014). reference ranges for serum uric acid among healthy 
assamese people. Biochemistry Research International. http://dx.doi.org/10.1155/2014/171053

Enomoto A, Kimura H, Chairoungdua A, Shigeta Y, Jutabha $P$, et al (2002). Molecular identification of a renal urate-anion exchanger that regulates blood urate levels. Nature 417, 447-452

Emmerson BT (1974). Effect of oral fructose on urate production. Ann Rheum Dis 33, 276-280

Emmerson BT (1996). The management of gout. N Engl J Med 334, 445-51

Fam AG (2002). Gout, Diet, and The Insulin Resistance Syndrome. J Rheumatol 29, 1350-1355

Hak AE, Choi HK (2008). Menopause, postmenopausal hormone use and serum uric acid levels in us women the third national health and nutrition examination survey. Arthritis Research \& Therapy 10, R116, doi: 10.1186/ar2519

Hauck OK, Scharnberg J, Escobar NM, Wanner G, Giavalisco P, Witte CP (2014). Uric acid accumulation in an arabidopsis urate oxidase mutant impairs seedling establishment by blocking peroxisome maintenance. The Plant Cell 26, 3090-3100

Heinig M, Johnson RJ (2006). Role of uric acid in hypertension, renal disease, and metabolic syndrome. Cleve Clin J Med 73,1059-1064

Karwur F, Triandhini R, 2016. A story with three tellers (abstract). international symposium on Austronesian Diaspora. 18th to 23rd July 2016. The National Research Centre of Archeology in Collaboration with The Directorate Cultural Heritage and Museums, Nusa Dua, Bali. Indonesia

Kobayashi T, Inokuchi T, Yamamoto A, Takahashi S, Ka T, Tsutsumi Z, Saito H, Moriwaki Y, Yamamoto T (2007). Effects of sucrose on plasma concentrations and urinary excretion of purine bases. Metabolism Clinical and Experimental 56, 439-443

Kolz M, Johnson T, Sanna S, Teumer A, Vitart V, et al (2009). Meta-analysis of 28.141 individuals identifies common variants within five new loci that influence uric acid concentrations. Plos Genetics 5, e1000504. doi: 10.1371/journal.pgen.1000504

Lee IR, Yang L, Sebetso G, Allen R, Doan THN, Blundell R, Lui YL, Morrow CA, Fraser JA (2013). Characterization of the complete uric acid degradation pathway in the fungal pathogen cryptococcus neoformans. Plos ONE 8(5)

Lehto S, Niskanen L, Ronnemaa T, Laakso M (1998). Serum uric acid is a strong predictor in patients with non-insulin-dependent diabetes mellitus. Stroke 29, 635-639

Löffler W, Gröbner W, Zöllner N (1981). Nutrition and uric acid metabolism: plasma level, turnover excretion. Fortschritte der Urol. und Nephrol 16, 8-18

Matsuo H, Yamamoto K, Nakaoka H, Nakayama A, Sakiyama M, et al (2015). Genome-wide Association Study of Clinically Defined Gout Identifies Multiple
Risk Loci and Its Association with Clinical Subtypes. Ann Rheum Dis, 1-8. doi : 10.113/annrheumdis.2014206191

Moriwaki Y, Ka T, Takahashi S, Tsutsumi Z, Yamamoto $T$ (2006). Effect of beer ingestion on the plasma concentrations and urinary excretion of purine bases : one-month study. Nucleosides, Nucleotides, and Nucleic Acids 25, 1085-1085

Nakayama A, Matsuo H, Takada T, Ichida K, Nakamura T, Ikebuchi Y, Ito K, Hosoya T, Kanai Y, Suzuki H, Shinomiya N (2011). ABCG2 is a high-capacity urate transporter and its genetic impairment increases serum uric acid levels in humans. Nucleosides Nucleotides and Nucleic Acids 30, 1091-1097

Nugent CA, Tyler FH (1959). The renal excretion of uric acid in patients with gout and in nongouty subjects. J Clin Invest 38, 1890-1898

Puig JG, Torres RJ, de Miguel E, Sánchez A, Bailén R, Banegas JR (2012). Uric acid excreton in healthy subjects: a nomogram to assess the mechanisms underlying purine metabolic disorders. Metabolism Clinical and Experimental 61, 512-518

Reginato AM, Mount DB, Yang I, Choi HK (2012). The genetics of hyperuricemia and gout. Nat Rev Rheumatol 8, 610-621

Rehman A, Naqvi SAJ (1980). Serum and Urinary Uric Acid in Relation to Age and Sex. JPMA 30, 242-244

Richette P, Bardin T (2010). Gout. Lancet 375, 318-28

Ryu KA, Kang HH, Kim SY, Yoo MK, Kim JS, Lee $\mathrm{CH}$, Wie GA (2014). Comparison of nutrient intake and diet quality between hyperuricemia subjects and controls in Korea. Clin Nutr Res 3, 56-63

Seegmiller JE, Grayzel AI, Laster L, Liddle L (1961). Uric acid production in gout. J Clin Invest 40, 13041314

Scott JT, Holloway VP, Glass HI, Arnot RN (1969). Studies of uric acid pool size and turnover rate. Ann rheum Dis 28, 366-373

Sorensen LB (1962). The pathogenesis of gout. Archives of Internal Medicine 109, 379-390

Sorensen LB (1965). Role of the intestinal tract in the elimination of uric acid. Arthritis and Rheumatism 8, 694-706

Sorensen LB (1980). Gout secondary to chronic renal disease: studies on urate metabolism. Annals of the Rheumatic Diseases 39, 424-430

Teng GG, Tan CS, Santosa A, Saag KG, Yuan J, Koh W (2013). Serum urate levels and consumption of common beverages and alcohol among Chinese in Singapore. Arthritis Care \& Research. 65, 1432-1440

Vitart V, Rudan I, Hayward C, Gray NK, Floyd J, et al (2008). SLC2A9 is a Newly identified urate transporter influencing serum urate concentration, urate excretion and gout. Nature Genetics 40, 437-442 
Vogels GD, van der drift C (1976). Degradation of purines and pyrimidines by microorganisms. Bacteriological Reviews 40, 403-468

Wang DD, Sievenpiper JL, de Souza RJ, Chiavaroli L, $\mathrm{Ha} \mathrm{V}$, et al (2012). The effects of fructose intake on serum uric acid vary among controlled dietary trials. J. Nutrition 142, 916-923

Webb R, Jeffries M, Sawalha AH (2009). Uric acid directly promotes human T-cell activation. Am J Med Sci 337(1), 23-27

Witkowska K, Smith KM, Yao SYM, Ng AML, O’Neill D, Karpinski E, Young JD, Cheeseman CI (2012). Human SLC2A9a and SLC2A9b isoforms mediate electrogenic transport of urate with different characteristics in the presence of hexoses. Am J Physiol Renal Physiol 303, 527-539

Yamamoto T, Moriwaki Y, Ka T, Takahasji S, Tsutsumi Z, Cheng J, Inokuchi T, Yamamoto A, Hada T (2004). Effect of sauna bathing and beer ingestion on plasma concentrations of purine bases. Metabolism 53(6), 772-776

Yang B, Mo Z, Wu C, Yang H, Yang X, et al (2014). A genome-wide association study identifies common varians influencing serum uric acid concentrations in a Chinese population. BMC Medical Genomics 7, 10, doi: $10.1186 / 1755-8794-7-10$ 